\title{
Developing Digital Dashboard Management for Learning System Dynamic Cooperative Simulation Behavior of Indonesia
}

\author{
(Study on Cooperative Information Organization in the Ministry of Cooperatives and SME)
}

\author{
Yuli Eni ${ }^{1}$, and Rudy Aryanto ${ }^{2}$ \\ School of Business Management, Bina Nusantara University, Jakarta, Indonesia \\ School of Business Management, Bina Nusantara University, Jakarta, Indonesia
}

\begin{abstract}
There are problems being experienced by the Ministry of cooperatives and SME (Small and Medium Enterprise) including the length of time in the decision by the Government to establish a policy that should be taken for local cooperatives across the province of Indonesia. The decision-making process is still analyzed manually, so that sometimes the decisions taken are also less appropriate, effective and efficient. The second problem is the lack of monitoring data cooperative process province that is too much, making it difficult for the analysis of dynamic information to be useful. Therefore the authors want to fix the system that runs by using digital dashboard management system supported by the modeling of system dynamics. In addition, the author also did the design of a system that can support the system. Design of this system is aimed to ease the experts, head, and the government to decide (DSS - Decision Support System) accurately effectively and efficiently, because in the system are raised alternative simulation in a description of the decision to be taken and the result from the decision. The system is expected to be designed dan simulated can ease and expedite the decision making. The design of dynamic digital dashboard management conducted by method of OOAD (Objects Oriented Analysis and Design) complete with UML notation.
\end{abstract}

Keywords-component; system dynamic, model, simulation, digital dashboard management, DSS

\section{INTRODUCTION}

The case of this research are utilization of information technology (information technology) can be used completely in cooperative business evaluation as stated in the form of a website on the internet in order to promote the Ministry of Cooperatives and SME organizational control and decision. The available resources to meet need a means of promotion, information and communication, the ministry of cooperatives and SME the republic of Indonesia has establishing and developing specifically for the website to cooperatives and SME stipulated in www.smecda.com.

Smecda.com is a intranets information system that existed in the state ministry of cooperatives and SME built by the deputy for cooperation and head of deputy for the development of SME affairs research resources cooperatives and SME. Intranets information system is developed because of problems like limited human resources (HR) and weakness structure capital or limited resources, as a result of this limitation automatic will obstruct access productive resources as a power source of raw materials, the market, capital, technology, information, and management. Hopefully with information system is expected to intranets the state ministry of cooperatives and SME can develop and objectify potentials individual from each division as well as could help to provide information, data required by the deputy head in the field of research resources cooperatives and SME.

Focusing on needs government institution in this is the ministry of cooperatives and SME for cooperation, especially head and administrative management in the ministry of cooperatives and SME for cooperation and head of deputy cooperatives and SME for assessment resources cooperatives and SME. The institution always trouble in doing granting information and data quickly for the Deputy Ministry in Jakarta. Consequently, the supervisors often took the data with manual way come straight to the server uses flash disk and others. Therefore, head need a system that has regularly arranged, structured well and accessible and understood, So that a head will give information and data via system to be constructed. Hence, to face this problems, needed software used as an appropriate solutions to help head in taking a making prompt. One of the solutions is to do an analysis and design model system dynamic digital dashboard management ministry cooperatives and SME.

Dynamic digital dashboard management will give a pages containing information key which needed by head to monitored, so head can find problem quickly, and give the action or proposes decision-making in order help improve performance of ministry of cooperatives and SME. Dashboard also will help create decision the swift exactly, and eventually could help improve the performance in ministry of Cooperatives and develop and to support mission being executed by ministry of cooperatives and SME namely provides information with regard to businesses devoted Cooperative and SME to boost the rise Indonesian economy..

\section{METHODS}

The methodology used in the collection of this data is: 1) The study of literature, by collect data and references from various studies literature as from books, journals or media that was available online and of course all the reference deals with topic digital dashboard management to 
be discussed more deeply to get information useful for the head in Jakarta. 2) Observation, the research and internal analysis done in the ministry of cooperatives and SME dept. to collect the data and determine factors determine the success in of cooperatives and UKM throughout Indonesia. 3) Interviews, to prepare a variety of questions that deals with the cooperatives and SME throughout Indonesia to get information to design a system of digital dashboard management that will be done by the writer.

A dynamic method of internal analysis internal of the company to be used in this research is a method of system dynamic simulation modeling (system dynamic unified). A system dynamic simulation modeling made in 3 stages, namely:

1. Conceptualizing the system is the basic data are obtained from the cooperative created a concept for next will be a modeling which aim to get a holistic picture about the model that will be created. Conceptualizing the system searchable an important factors that needs to be in the Ministry of cooperatives and SME, can then be described as causal diagram is closed loop at the following.

Closed loop at Causal (representations of causal relations): Depiction of a system by using the method of system dynamic i.e. causal representations of closed loop at. This is a closed loop at causal disclosure about the incident about the causal relationships in the field of study resources Ministry Deputy, cooperatives and SME specifically are in the areas of partnership and networking, which can be described as figure 1 .

2. Formulations model is actually formularization meaning of any relation that exists in a great conceptual model done by means of quantitative insert data into a diagram model. Formulations this model can be described in the form of a flow diagram. Flow diagram is disclosure about the incident about the relationship of causality in ministry deputy for assessment resources , cooperatives and SME that specifically being in areas of cooperation and tissue, that can be described as figure 2:

Flow diagram above a continuation of causal loop; but inside flow diagram is described more specific by symbols a distinctive symbol of the appointed

3. Evaluation model consisting of two types, i.e. verification model (carried to know whether model that will be made consistent or not) and validation model (carried testing structure directly without running model) . Evaluation model is conducted by using formulas down here, to verify whether model used in accordance or not, and adjusted with needs in the Ministry of Cooperatives and SME .

\section{DESIGN AND DISCUSSION}

Analysis method to be used in this research is need analysis system done by means of acknowledges information so required by advisors cooperatives and UKM throughout Indonesia, which in this relates to internal of data center in the cooperative and SME DKI Jakarta. The analysis conducted to identity present business process and conditions proposed. Following this is a depiction of business process existing in the Ministry of cooperatives and SME. Analysis of Proposed Systems Condition: Based on the systems analysis that runs then can made a system that were proposed in the rich picture to help the head in overcoming existing problems, as figure 3 and table 1 follows.

Table 1 Decline Analysis into the design of the system

\begin{tabular}{|c|c|c|c|}
\hline No. & $\begin{array}{c}\text { Problems and Needs } \\
\text { Analysis }\end{array}$ & Demand & Feature \\
\hline 1 & $\begin{array}{l}\text { The difficulty the } \\
\text { government and the } \\
\text { head in taking a } \\
\text { decision quickly, } \\
\text { effective and efficient in } \\
\text { do control in any } \\
\text { transaction distribution } \\
\text { assistance and venture } \\
\text { capital to all } \\
\text { cooperatives around } \\
\text { Indonesia } \\
\text { (aspect } \rightarrow \text { time) }\end{array}$ & $\begin{array}{l}\text { The } \\
\text { Government } \\
\text { and the } \\
\text { Kabid can } \\
\text { see the data } \\
\text { extensively }\end{array}$ & $\begin{array}{l}\text { View the graph } \\
\text { described in the } \\
\text { system can see the } \\
\text { cooperative } \\
\text { transactions per } \\
\text { year and per } \\
\text { province in outline. } \\
\text { b. the existence of } \\
\text { alternative decisions } \\
\text { in the present in the } \\
\text { form of graph } \\
\text { interpretation. }\end{array}$ \\
\hline 2 & $\begin{array}{l}\text { The difficulty to make } \\
\text { search and tracing data } \\
\text { cooperative to produce } \\
\text { information against } \\
\text { cooperatives consistent } \\
\text { from year to year. } \\
\text { (aspect } \rightarrow \text { accuracy of } \\
\text { information) }\end{array}$ & $\begin{array}{l}\text { Cooperative } \\
\text { Data } \\
\text { consistently } \\
\text { arranged and } \\
\text { structured }\end{array}$ & $\begin{array}{l}\text { Search information } \\
\text { up at the provincial } \\
\text { level. } \\
\text { Recapitulation } \\
\text { report province per } \\
\text { year }\end{array}$ \\
\hline 3 & $\begin{array}{l}\text { The Government and } \\
\text { the Kabid difficult to } \\
\text { decide policy for each } \\
\text { individual province } \\
\text { cooperatives. } \\
\text { (aspect } \rightarrow \text { policy } \\
\text { decisions) }\end{array}$ & $\begin{array}{l}\text { The } \\
\text { Government } \\
\text { and the } \\
\text { Kabid } \\
\text { requires } \\
\text { presentation } \\
\text { of complete } \\
\text { data and } \\
\text { neatly. }\end{array}$ & $\begin{array}{l}\text { Presentation of data } \\
\text { in the form of } \\
\text { graphs as well as } \\
\text { alternative policy } \\
\text { dashboard decisions } \\
\text { in view of } \\
\text { calculating charts } \\
\text { on the future }\end{array}$ \\
\hline
\end{tabular}

Method of design, using object-oriented approach (OOAD) pictured with the notation Unified Modeling Language (UML) such as: Use Case diagrams, Class diagrams, Sequence Diagrams, and Component diagrams. This method of design is also based on the theory of OOAD book written by Mathiassen et al (2000). especially in sequence diagrams using Bennett et al. Additionally also done database design diagram, navigation, and user interface is needed in designing digital dashboard management, i.e. figure 4 .

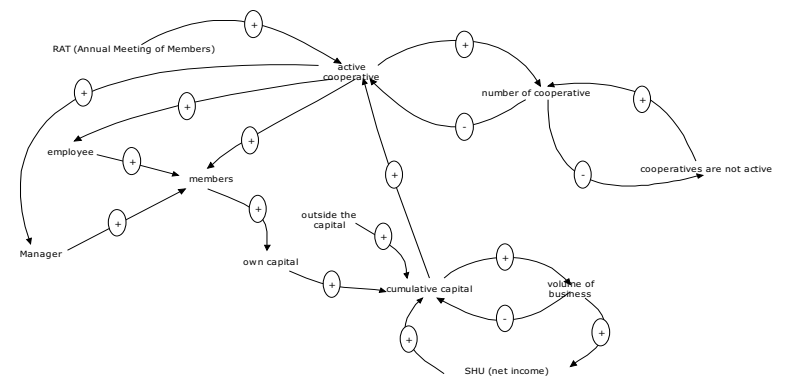

Figure 1. Cooperatives System Dynamic Closed loop 


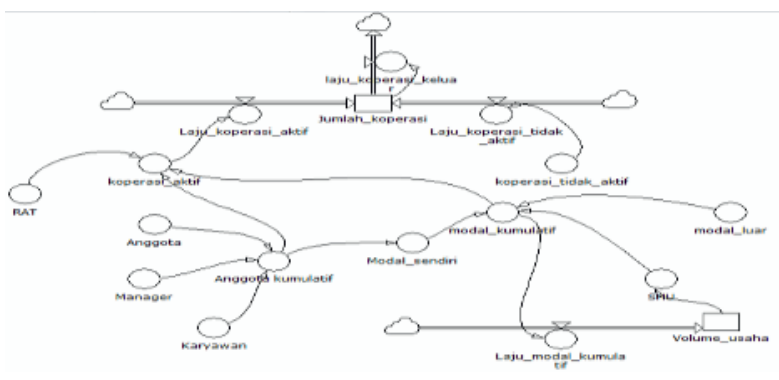

Figure 2. Flow diagram

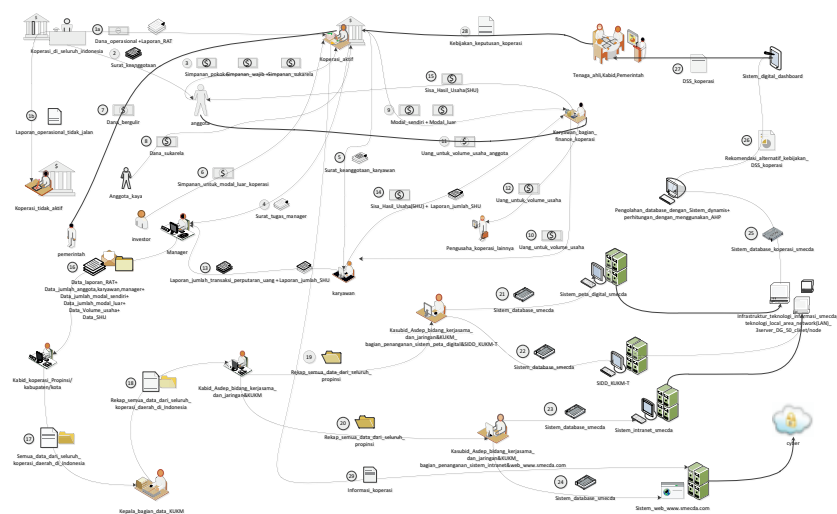

Figure 3. Rich Picture Conditions

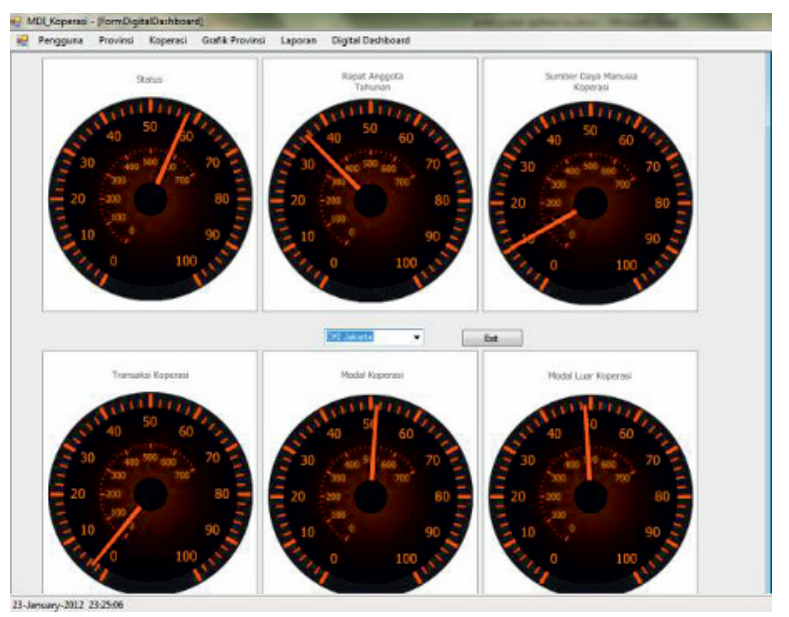

Figure 4. Interface Digital Dashboard Management

\section{CONCLUSION}

Based on the analysis and design digital system management dashboard drawing conclusions to be drawn is:

From the results of the formulation of the strategy with the three stages of the framework on the Ministry field of cooperation and development dissemination network Deputy Assistant Affairs Deputy SME resource assessment areas, cooperatives, and SME (stage, stage design, analysis and phase matching) generate simulated scenarios which can be used to view the current cooperative conditions and forecasting conditions for each province. Simulation of these systems can assist in monitoring the development of cooperatives per province. It is also a solution of the problems faced by the Ministry field of cooperation and development dissemination network Deputy Assistant Affairs Deputy SME resource assessment areas, cooperatives, and SME in terms of viewing data thoroughly cooperative.

Model of information system proposed for support of the existing management information systems in the Ministry field of cooperation and development dissemination network Deputy Assistant Affairs Deputy SME resource assessment areas, cooperatives, and SME, namely the model of information system based on desktop application.

From the results of an analysis system that runs it is known that there are some problems faced by the Ministry field of cooperation and development dissemination network Deputy Assistant Affairs Deputy SME resource assessment areas, cooperatives, and SME related to do with monitoring data cooperative, providing data and information to the entire Kabid, Deputy Assistant, and Kasubbid related that needs data cooperative. The problems associated with the cooperative data for example are (a) the difficulty of Deputy Assistant and Kabid in conducting monitoring cooperative transaction per province all over Indonesia; (b) the difficulty of searching and information retrieval of cooperatives per province all over Indonesia.

Designing a digital system management dashboard is the result of a decrease in strategy and analysis of the issues that have been discussed in Chapter 3. Digital dashboard system management system designed to provide facilities that make it easy for Government, Deputy Assistant, and Kabid in taking decisions and find the needed information is certainly related data cooperative data per province all over Indonesia.

Designing a digital dashboard system management can provide information and DSS (Decision Support System) about cooperative per province all over Indonesia which was presented in the form of a Digital Dashboard 


\section{REFERENCES}

1. Bennet, Simon; McRobb, Steve; dan Farmer, Ray. (2006). Object Oriented Systems Analysis and Design Using UML. ( $3^{\text {rd }}$ Ed.). McGraw-Hill, New York.

2. Deputi bidang kerjasama dan jaringan asdep urusan pengembangan perkaderan UKM deputi bidang pengkajian sumberdaya UKMK (2011). Jakarta.

3. Few, Stephen. (2006). Information Dashboard Design: The Effective Visual Communication of Data. Sebastopol: O'Reilly Media Inc.

4. Khosrow-Pour, Mehdi.(2009). Encyclopedia of Information Science and Technology. ( $2^{\text {nd }}$ ed.).United States: IGI Global.

5. Kuncoro, E.A dan Riduwan. (2007). Cara Menggunakan dan Memaknai Analisis Jalur (Path Analysis). Bandung: Penerbit Alfabeta.

6. Laudon \& Laudon.(2006). Management Information Systems: Managing the Digital Firm. United States: Prentice Hall.

7. Mathiassen, L., Munk-Madsen, A., Nielsen, P. A., \& Stage, J. (2000). Object Oriented Analysis \& Design (1 ed.). Denmark: Forlaget Marko.

8. McLeod, J. R., Schell, G., Stonehill, A. I., \& Moffet, M. H. (2004) Sistem Informasi Manajemen (8 ed.). (H. Teguh, Penerj.) Jakarta: PT Indeks.

9. Moeis, A. O., Hidayatno, A., \& Satrio, M. (2005). Pembuatan Permainan Simulasi Bisnis "Executive Decision” Dengan Pendekatan
Sistem Dinamis Untuk Meningkatkan Pembelajaran. (E. K. No.2, Penyunt.) Jurnal Teknologi, 6.

10. Muhammadi, Aminullah, E., \& Soesilo, B. (2001). Analisis Sistem Dinamis (Lingkungan Hidup, Sosial, Ekonomi, Manajemen) (Pertama ed.). Jakarta: UMJ Press.

11. McKeen, James D., Smith, Heather A., Singh, Satyendra.(2005). Developments in Practice XX - Digital Dashboards: Keep Your Eyes on the Road. Communications of the Association for Information Systems. 16(52). 1014-1016.

12. Nasution, M. (2001). Koperasi (Konsepsi, Pemikiran, dan Peluang Membangun Masa Depan Bangsa). Jakarta.

13. O'Brien, J. A. (2006). Pengantar Sistem Informasi: Perspektif Bisnis dan Manajerial (12 ed.). (D. Fitriasari, \& D. A. Kwary, Penerj.) Jakarta: Salemba Empat.

14. Prodip-Stan (2011). Microsoft Visual Basic. Diperoleh (tanggal akses 10 januari 2012) dari http://prodip-stan.info/microsoft-visual-basic

15. Rasmussen, N., Chen, C. Y., \& Bansal, M. (2010). Business Dashboard (Mengendalikan Bisnis Melalui Layar Monitor) (1 ed.). (A. C. Suci, Penerj.) Jakarta: Penerbit PPM Manajemen.

16. Soesilo, M. I. (2008). Dinamika Gerakan Koperasi Indonesia. Jakarta: PT. Wahana Semesta Intermedia.

17. Taylor, \& Francis. (2009). Dynamical Systems. Dynamical Systems International Journal , 25, 9.

18. Tim Deputi Bidang Pengembangan Sumber Daya Manusia Kementerian Koperasi dan UKM. (2011). Jakarta. 